\title{
Evolution of textural characteristics of surfactant-mediated mesoporous zirconia aerogel powders prepared via ambient pressure drying route
}

\author{
Uzma K. H. Bangi ${ }^{1} \cdot$ Hyung-Ho Park ${ }^{2}$
}

Received: 26 March 2018 / Accepted: 4 July 2018 / Published online: 7 July 2018

(c) The Author(s) 2018

\begin{abstract}
The experimental results in this work represent the preparation of ambient pressure dried zirconia aerogels using surfactant and their textural characteristics studies. Zirconia aerogel powders were prepared by sol-gel process employing Brij-76 as a surfactant. The influence of varying concentrations of Brij-76 $(0.01-0.1 \mathrm{M})$ on the textural characteristics of zirconia powders was studied. During synthesis, the molar ratio of Zirconium $n$-propoxide: $n$-Propanol: Acetic acid: $\mathrm{H}_{2} \mathrm{O}$ was kept fix to 1:16.8:2.7:8.7. The structural and morphological observations of these powders were performed through X-ray diffraction analysis and field emission scanning electron microscopy (FESEM). The surface area and average pore diameter of the synthesized powders were estimated using $N_{2}$ adsorption-desorption analysis. Zirconia powders obtained using Brij-76 $(0.01 \mathrm{M})$ without any heat treatment exhibited the amorphous nature with a well-ordered mesoporous morphology, specific surface area, and average pore of nearly $177 \mathrm{~m}^{2} / \mathrm{g}$ and $60 \AA$, respectively.
\end{abstract}

Keywords Brij-76 $\cdot$ Sol-gel preparation $\cdot$ Ambient pressure drying $\cdot$ Mesoporous $\cdot$ Zirconia powders $\cdot$ Surface area

\section{Introduction}

"Aerogels, the lightest and transparent nanostuctured materials, are obtained from a gel by the replacement of liquid present in the pores of gel with air". They are extremely low dense materials with a wide variety of outstanding properties such as low thermal conductivity, high porosity and large surface area [1-3]. Exhibiting such exceptional properties, aerogels are applicable in various fields such as thermal insulation, catalysis and sensors, etc. $[4,5]$. The preparation of aerogels can be performed through supercritical drying (drying above critical temperature $\left(T_{\mathrm{c}}\right)$ and

Electronic supplementary material The online version of this article (https://doi.org/10.1007/s40089-018-0241-7) contains supplementary material, which is available to authorized users.

Uzma K. H. Bangi

uzma.phys@gmail.com

1 School of Physical Sciences, Solapur University, Solapur-Pune National Highway, Kegaon, Solapur, Maharashtra 413 255, India

2 Department of Materials Science and Engineering, Yonsei University, Seoul 120-749, Republic of Korea pressure $\left(P_{\mathrm{c}}\right)$ of liquid present in the pores of gel) or ambient pressure drying (drying at ambient pressure and temperature $>150^{\circ} \mathrm{C}$ ) or freeze drying (drying of frozen gel in vacuum) methods. Recent developments have shown great potential of the ambient pressure drying as an alternative and simple method for the synthesis of aerogels replacing the expensive and energy intensive methods of supercritical and freeze drying. Following this, till date the synthesis and characterizations of zirconia $\left(\mathrm{ZrO}_{2}\right)$ aerogels via ambient pressure drying was reported by few research groups [6-8]. These reports manifested the studies on the influence of propylene oxide as complexing agent, hydrolysis water, and heat treatment on the pore size and surface area of zirconia aerogels. It is well known that the pore sizes in the materials (bulk or thin film) can be controlled in the mesopore range (2-50 $\mathrm{nm}$ ) by addition of surfactant (organic additive) which acts as structure directing agents $[9,10]$. Because of the small pore sizes, the mesoporous materials have found extensive applications in the field of designing catalyst support, templates, adsorbents and solid oxide fuel cells [11-15]. To obtain mesoporous structures, the surfactants like Brij-76, Brij-58 and Pluronic F127 are being used for the network-formation. The surfactant mediated synthesis of mesoporous materials can be considered as the electrostatic 
interactions between the ions of metal species and the head groups of charged surfactant as well as the hydrogen bonding interactions between the neutral primary amine micelles, and neutral inorganic species $[16,17]$. The work on the synthesis of titania- and zirconia-based mesoporous materials has been reported by elsewhere $[18,19]$. Much attention is focussed on the $\mathrm{ZrO}_{2}$-based catalyst since it has acidic and basic character as well as oxidizing and reducing chemical properties. Moreover, zirconia aerogels exhibit good textural characteristics which help to enhance the catalytic activity, thermal stability, and resistance to poisoning [20]. There are several reports on the catalytic applications of zirconia aerogels related to the modification of their surfaces by metals (copper, iron) or ions (sulfate, phosphate, tungstate) and to the use of surfactant like cetyl trimethyl ammonium bromide (CTAB), octyl trimethyl ammonium bromide (OTAB), etc. The catalytic performances of zirconia xerogels and aerogels were studied in the dehydration of methylpentan-2-ol reaction and $\mathrm{CO}=\mathrm{CO}_{2}$ hydrogenation by few research groups [21, 22]. Kalies et al. presented the catalytic activity of $\mathrm{Pt}$ doped zirconia aerogel for hydrogenation of methoxy moieties [23]. Suh et al. reported the catalysis of surfactant (CTAB and OTAB) mediated zirconia in the skeletal isomerization of 1-butene [24]. Further, the catalytic properties of sulfated zirconia aerogels and xerogels at various calcination temperatures were studied by Ghorbel et al. [25]. The sulfated zirconia aerogels doped with cerium were found to have higher acidity leading to their good activity in n-hexane isomerization reaction in the wide temperature range [26]. Interestingly, the iron-doped zirconia solid solution aerogels exhibited an excellent catalytic performance for the solvent-free aerobic oxidation of $n$-hexadecane which can be recycled five times without significant loss of activity [27]. Moreover, mesoporous sulfated zirconia aerogels doped with chromium showed the improvement of $n$-hexane isomerization reaction by burning-off coke [28].

Similar to mesoporous zirconia, the pore sizes in zirconia aerogels may also be tuned in mesopore range using surfactant during the sol-gel process and drying at ambient pressure. The as synthesized zirconia aerogels can be applied as a catalyst in replacement to supercritically dried zirconia aerogels. Therefore, it is challenging to synthesize high surface area mesoporous zirconia aerogels via ambient pressure drying. Till date, to the best of our knowledge there are rare reports on the synthesis of ambient pressure dried zirconia aerogels employing surfactant. Therefore, in the present work Brij-76 was used as a surfactant for the synthesis of zirconia aerogels. Brij-76 is also known as stearyl ether with the chemical formula $\mathrm{C}_{18} \mathrm{H}_{37}\left(\mathrm{OCH}_{2} \mathrm{CH}_{2}\right)_{10} \mathrm{OH}$. Brij-76 is a non-ionic surfactant consisting of hydrophobic tail (long alcohol chain) and hydrophilic head (polyoxyethylene) [29]. So, in the present report, zirconia aerogels were synthesized using Brij-76 as a surfactant and the influence of varying concentration of Brij-76 (0.01-0.1 M) on their textural characteristics has been studied.

\section{Experimental}

For the synthesis of zirconia aerogel powders, zirconium $n$-propoxide $\left(\mathrm{Zr}\left(\mathrm{OC}_{3} \mathrm{H}_{7}\right)_{4}, 70 \%\right.$ in $n$ - $\mathrm{PrOH}$, SigmaAldrich), $n$-propanol ( $n$-PrOH, SD Fine), acetic acid glacial $\left(\mathrm{CH}_{3} \mathrm{COOH} / \mathrm{HOAc}, \mathrm{SD}\right.$ FIne $)$ and Brij-76 $\left(\mathrm{C}_{58} \mathrm{H}_{118} \mathrm{O}_{21}\right.$, Aldrich, MW 711) were used as precursor, solvent, catalyst/ complexing agent and surfactant, respectively. Hexane was used as the exchanging and silylating solvent with hexamethyldisilazane (HMDZ) as a silylating agent. D. I. water was used for hydrolysis and condensation purpose. The flowchart for the synthesis of zirconia aerogel powders using Brij-76 is depicted in Fig. 1. During the synthesis, $0.5 \mathrm{M} \mathrm{Zr}^{4+}$ in $n$-PrOH was used [20] along with the $\mathrm{Zr}^{4+}$ :Acetic acid (glacial) molar ratio of 1:2.5 [30]. For the given concentration of $\mathrm{Zr}^{4+}$, D.I. $\mathrm{H}_{2} \mathrm{O}$ was added till the gel formed. Therefore,

\section{Solution 1: Propanol + Zirconium propoxide + Acetic acid (glacial) + D.I. $\mathrm{H}_{2} \mathrm{O}$}

\section{Solution 2: $\quad$ Propanol + Brij-76}

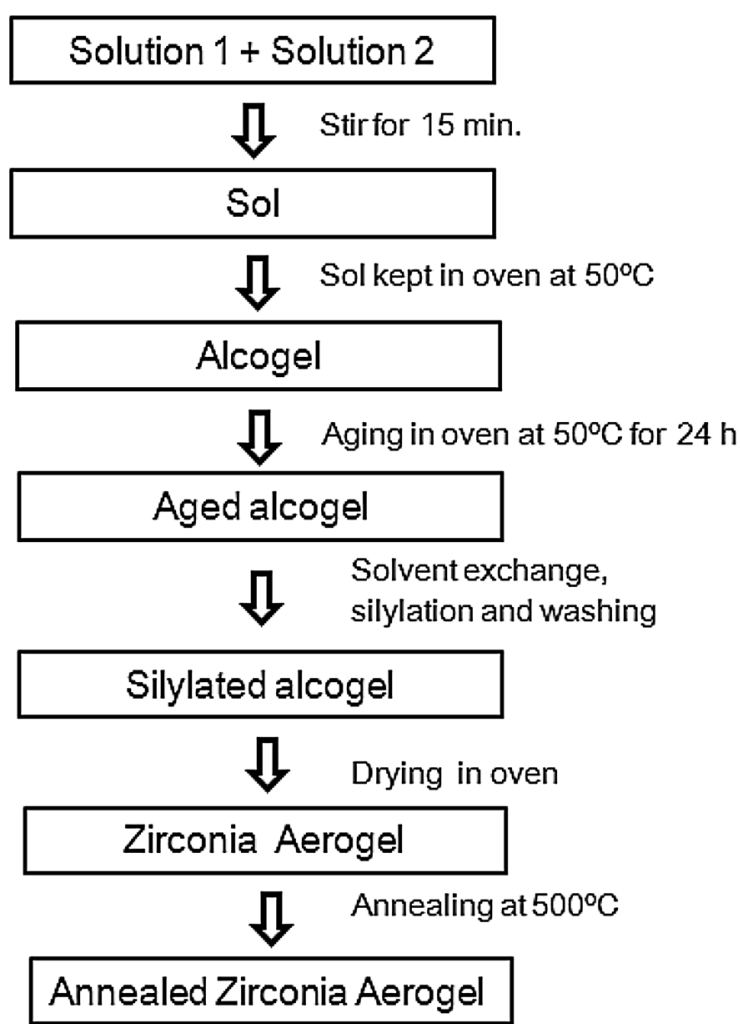

Fig. 1 Flowchart for the synthesis of zirconia aerogel powders 
the final molar ratio of Zirconium $n$-propoxide: $n$-Propanol: Acetic acid: $\mathrm{H}_{2} \mathrm{O}$ was kept constant at 1:16.8:2.5:8.7 and the concentration of Brij-76 was varied from 0.01 to $0.1 \mathrm{M}$ with the increment of $0.05 \mathrm{M}$ between each step. To prepare zirconia alcogels, two different solutions were formed and named as solution 1 and solution 2. Solution 1 consisted of the mixture of $n$-propanol, zirconium precursor, acetic acid and D.I. $\mathrm{H}_{2} \mathrm{O}$ while solution 2 was made up of $n$-propanol and Brij-76. Both the solutions were stirred for $1 \mathrm{~h}$ and mixed which again stirred for $15 \mathrm{~min}$ to give alcosols. This alcosol was kept at $50{ }^{\circ} \mathrm{C}$ in PID controlled oven to form alcogels. The sol-gel reactions taking place during alcogel formation are given below (reactions 1-5).

$$
\begin{gathered}
\text { Modification : } \mathrm{Zr}\left(\mathrm{OC}_{3} \mathrm{H}_{7}\right)_{4}+\mathrm{HOAc} \\
\quad \rightarrow \mathrm{Zr}\left(\mathrm{OC}_{3} \mathrm{H}_{7}\right)_{3}(\mathrm{OAc})+\mathrm{C}_{3} \mathrm{H}_{7} \mathrm{OH}
\end{gathered}
$$

Esterification : $\mathrm{HOAc}+\mathrm{C}_{3} \mathrm{H}_{7} \mathrm{OH} \rightleftharpoons \mathrm{C}_{3} \mathrm{H}_{7} \mathrm{OAc}+\mathrm{H}_{2} \mathrm{O}$

$$
\begin{aligned}
& \text { Hydrolysis : } \mathrm{Zr}\left(\mathrm{OC}_{3} \mathrm{H}_{7}\right)_{3}(\mathrm{OAc})+\mathrm{H}_{2} \mathrm{O} \\
& \quad \rightarrow \mathrm{Zr}\left(\mathrm{OC}_{3} \mathrm{H}_{7}\right)_{2}(\mathrm{OAc})(\mathrm{OH})+\mathrm{C}_{3} \mathrm{H}_{7} \mathrm{OH}
\end{aligned}
$$

Oxolation : $\mathrm{Zr}\left(\mathrm{OC}_{3} \mathrm{H}_{7}\right)_{2}(\mathrm{OAc})(\mathrm{OH})$

$$
\rightarrow \mathrm{ZrO}\left(\mathrm{OC}_{3} \mathrm{H}_{7}\right)(\mathrm{OAc})+\mathrm{C}_{3} \mathrm{H}_{7} \mathrm{OH}
$$

Further condensation : $\mathrm{ZrO}\left(\mathrm{OC}_{3} \mathrm{H}_{7}\right)(\mathrm{OAc})$

$$
\rightarrow \text { macromolecules } \rightarrow \text { Alcogel }
$$

These alcogels were subsequently subjected to aging (at $50{ }^{\circ} \mathrm{C}$ for $24 \mathrm{~h}$ ), solvent exchange with hexane (at $50{ }^{\circ} \mathrm{C}$ for $24 \mathrm{~h}$ ), silylation using mixture of 5\% HMDZ in hexane, again washing with hexane (at $50^{\circ} \mathrm{C}$ for $24 \mathrm{~h}$ ) and finally drying at $50^{\circ} \mathrm{C}$ (for $1 \mathrm{~h}$ ) and $150^{\circ} \mathrm{C}$ (for $2 \mathrm{~h}$ ) to obtain zirconia aerogels. The obtained zirconia aerogels are in powder form. A set of six zirconia samples was prepared with and without Brij-76 and named as listed below in Table 1. Out of six, four samples were heat treated at $500{ }^{\circ} \mathrm{C}$ for $1 \mathrm{~h}$ with the rate of $10{ }^{\circ} \mathrm{C} / \mathrm{min}$ in air atmosphere.

To know the amorphous or crystalline nature of zirconia aerogels, powder X-ray diffraction (XRD, RIGAKU Ultima IV diffractometer, Japan) was carried out using $\mathrm{Cu}$

Table 1 Notation for as synthesized zirconia aerogel powders

\begin{tabular}{ll}
\hline Sample id & Zirconia aerogels \\
\hline ZA1 & w/o Brij-76 and w/o heat treatment \\
ZA2 & With Brij-76 $(0.01 \mathrm{M})$ and w/o heat treatment \\
ZA3 & w/o Brij-76 heat treated at $500{ }^{\circ} \mathrm{C}$ \\
ZA4 & With Brij-76 $(0.01 \mathrm{M})$ heat treated at $500{ }^{\circ} \mathrm{C}$ \\
ZA5 & With Brij-76 $(0.05 \mathrm{M})$ heat treated at $500{ }^{\circ} \mathrm{C}$ \\
ZA6 & With Brij-76 $(0.1 \mathrm{M})$ heat treated at $500{ }^{\circ} \mathrm{C}$ \\
\hline
\end{tabular}

$\mathrm{K} \alpha(\lambda=1.541 \AA)$ radiation operated at $40 \mathrm{kV}$ and $30 \mathrm{~mA}$. The morphological study was performed using field emission scanning electron microscopy (FESEM, JEOL JSM$600 \mathrm{~F}$, Japan). The surface area and average pore diameter were obtained from the $\mathrm{N}_{2}$ adsorption-desorption analysis recorded at $77 \mathrm{~K}$ using a TriStar $3000 \mathrm{~V} 6.05 \mathrm{~A}$, USA. The chemical bonds present in the zirconia samples were analyzed by Fourier transform infra red spectroscopy (FTIR, Thermo Nexus 670).

\section{Results and discussion}

The amorphous or crystalline nature of zirconia aerogel powders was confirmed from the X-ray diffractograms as shown in Fig. 2. As seen from Fig. 2a it is observed that sample ZA2 manifested two broad peaks indicating the nanocrystalline amorphous nature of zirconia aerogels which is due to drying at $150{ }^{\circ} \mathrm{C}$ only. While sample ZA4 exhibited the tetragonal crystalline nature (Fig. $2 \mathrm{~b}$ ) because of the heat treatment at $500{ }^{\circ} \mathrm{C}$ as reported elsewhere [8]. This diffractogram matches with the JCPDS data card number PDF\#791,767 with a sharper and stronger peak of (101) indicating phase orientation along $\langle 101\rangle$. Figure 3 illustrates the FESEM images of the synthesized zirconia samples ZA1-ZA6. From the FESEM micrographs, it is clear that zirconia particles are loosely connected with each other randomly to form a sponge-like shape in case of sample ZA1 (Fig. 3a) while an ordered porous morphology is observed for sample ZA2 due to the presence of Brij-76 (0.01 M) (Fig. 3b). On the other hand for the samples ZA3-ZA6, a dense morphology is observed (Figs. 3c-f). The reason behind this is, the samples ZA1 and ZA2 were dried only at $150{ }^{\circ} \mathrm{C}$ and other samples ZA3-ZA6 were heat treated at $500{ }^{\circ} \mathrm{C}$ which caused the aggregation of particles. The influence of Brij -76 on the morphology of aerogel (samples ZA1 and ZA2) can be well understood from the pictorial representation as drawn in Fig. 4. In case of zirconia aerogel w/o Brij-76 (sample ZA1), the particles of zirconia in the sol condensate to form porous gel network which after drying form the aerogels with non-uniform larger pores. While in case of zirconia aerogels with Brij-76 (0.01 M) (sample ZA2), the zirconia particles condensate to form gel with uniform pores resulting in aerogels with ordered small pores on drying.

The influence of employing Brij-76 on the surface area and pore size distribution of zirconia samples was studied through $N_{2}$ adsorption-desorption analysis. Figure 5a, b exhibits the hysteresis isotherms of the zirconia samples ZA1-ZA3 and ZA4-ZA6, respectively. As shown in Fig. 5, all the zirconia samples ZA1-ZA6 exhibited type IV isotherm indicating the capillary condensation taking place in 
Fig. 2 X-ray diffractograms of the zirconia samples a ZA2, b ZA4

Fig. 3 FESEM images of zirconia samples a ZA1, b ZA2, c ZA3, d ZA4, e ZA5, f ZA6
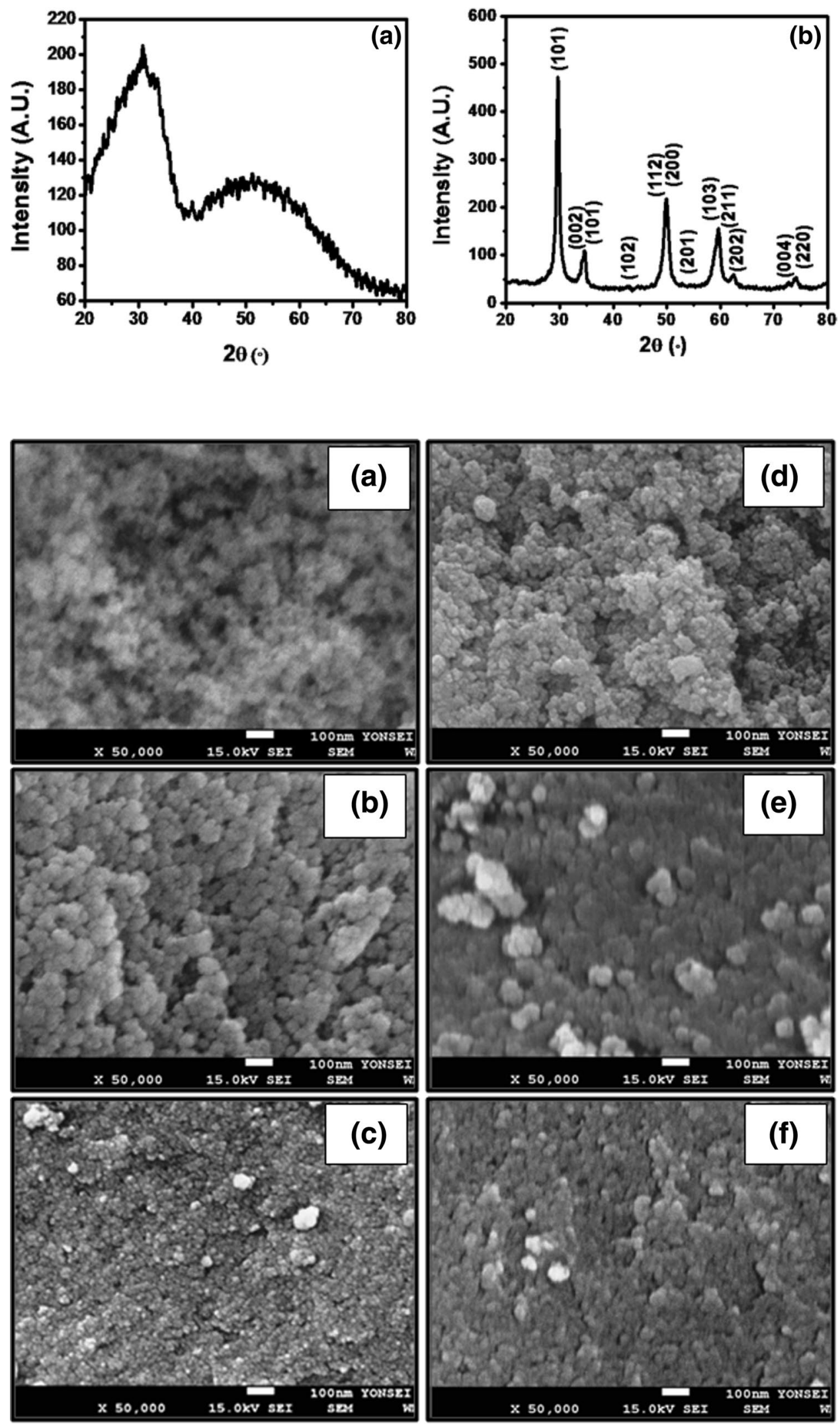


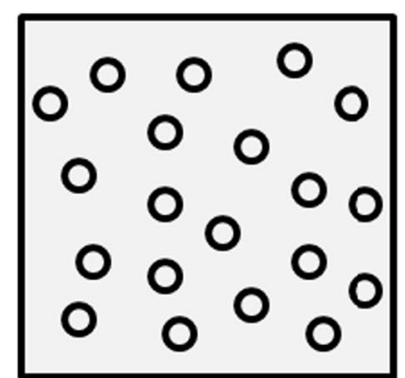

Zirconia sol w/o Brij-76

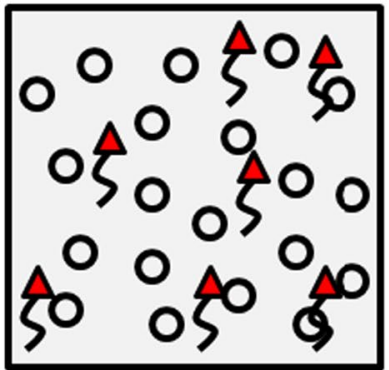

Zirconia sol with

$\operatorname{Brij-76}(0.01 \mathrm{M})$

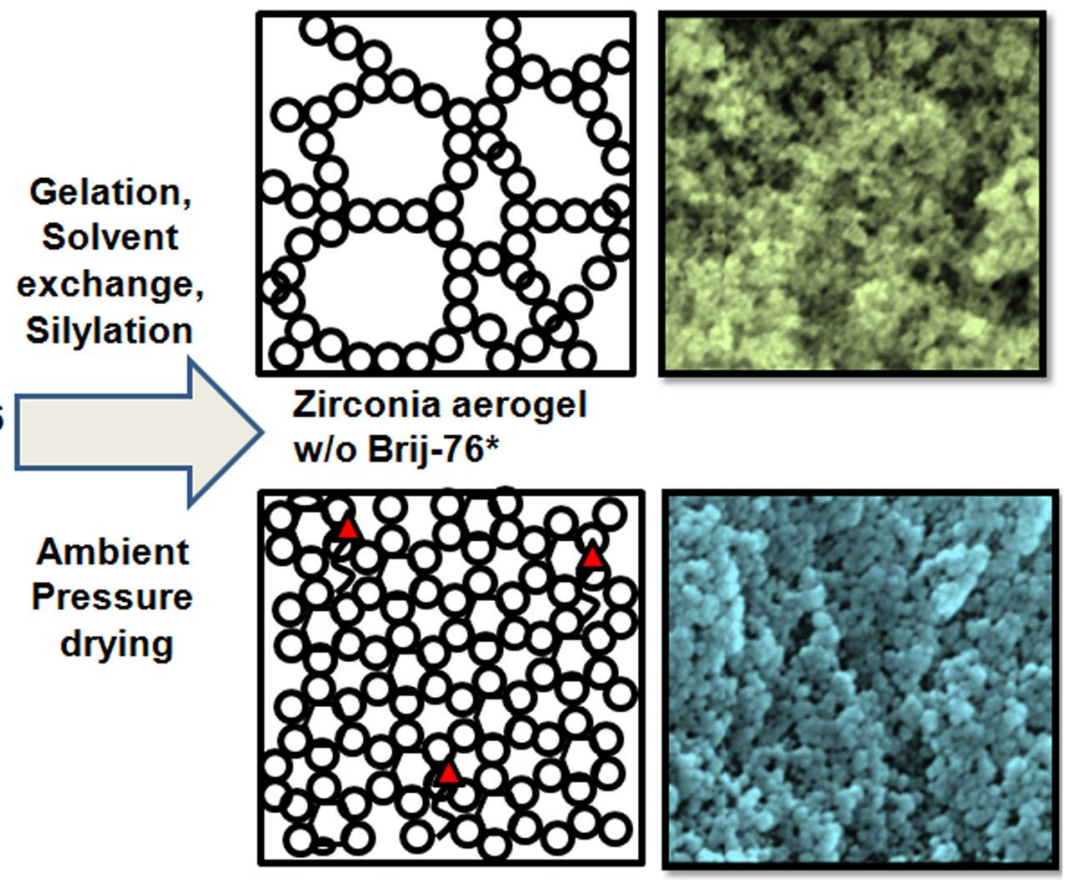

Zirconia aerogel with Brij-76 (0.01 M)*

Fig. 4 Pictorial representation for the formation of zirconia samples ZA1 (w/o Brij-76) and ZA2 (with Brij-76)

the mesopores [31]. The isotherms of samples ZA1 (Fig. 5a) and ZA5 (Fig. 5b) manifested the hysteresis loop of type $\mathrm{H}_{1}$ indicating the cylindrical pore geometry and facile pore connectivity. And the samples ZA2 and ZA3 (Fig. 5a), ZA4 and ZA6 (Fig. 5b) exhibited hysteresis loop of type $\mathrm{H}_{4}$ and $\mathrm{H}_{2}$ related to narrow slit-like pores and pores with narrow mouths, respectively. The pore size distribution of all the zirconia samples is shown in Fig. 6. All of the samples exhibited a broad, asymmetrical pore size distribution in the mesopore range as observed from Fig. 6. In case of sample ZA2, a sharp intense peak is observed at nearly $40 \AA$ along with a broad peak at around $180 \AA$ (Fig. 6a). But in case of the sample ZA4 (Fig. 6b) most of the volume is occupied by the mesopores as confirmed from the sharp intense peak centred around $40 \AA$. The BET surface area, pore volume and average pore diameter of aerogel powders obtained from $\mathrm{N}_{2}$ adsorption-desorption analysis are listed in Table 2 . The sample ZA1 has higher surface area of $204 \mathrm{~m}^{2} / \mathrm{g}$ and pore volume of $0.37 \mathrm{cc} / \mathrm{g}$ compared to the sample ZA2 possessing surface area of around $177 \mathrm{~m}^{2} / \mathrm{g}$ and pore volume of nearly $0.27 \mathrm{cc} / \mathrm{g}$. The reason behind this may be the occupancy of Brij-76 in the voids of zirconia aerogels [32]. The high surface area and pore volume of the samples ZA1 and ZA2 is due to well-ordered mesostructure, which can be confirmed
Fig. $5 \quad N_{2}$ adsorption-desorption isotherms of the zirconia samples
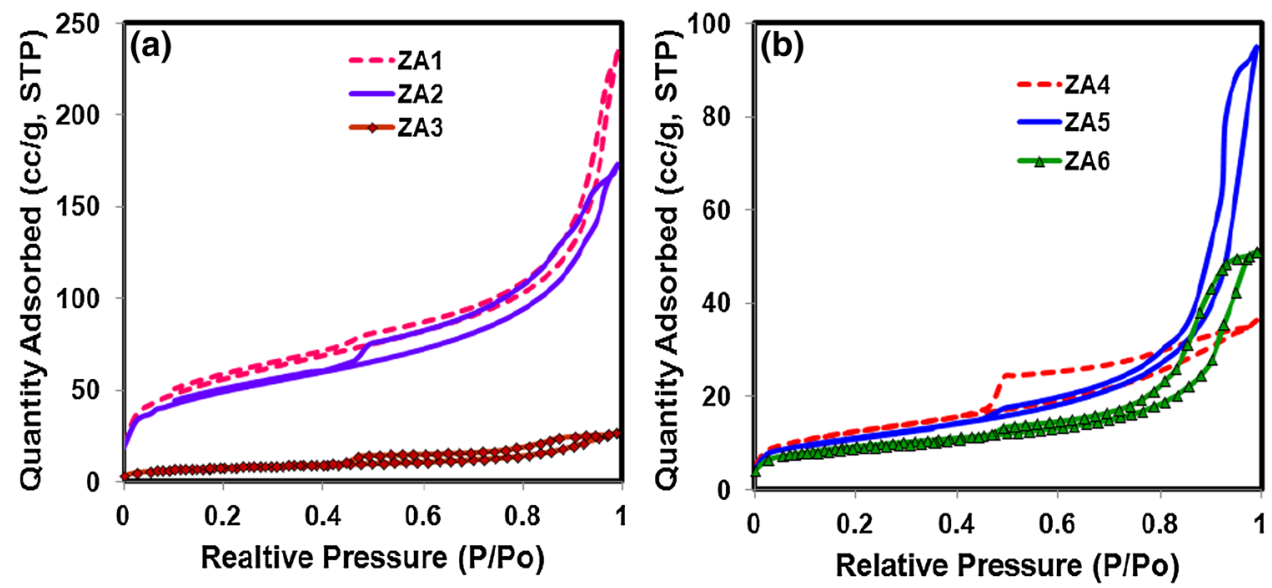
Fig. 6 Pore size distribution of the zirconia samples

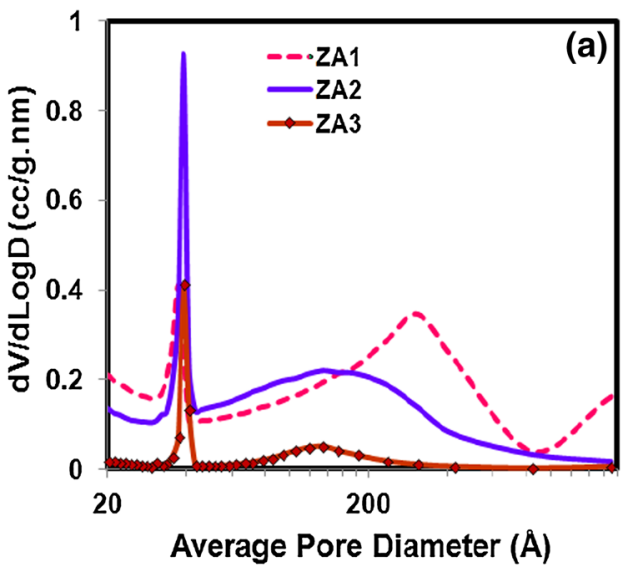

Table 2 BET surface area, pore volume, and average pore diameter of the zirconia samples

\begin{tabular}{lclc}
\hline Sample id & $\begin{array}{l}\text { BET surface area } \\
\left(\mathrm{m}^{2} / \mathrm{g}\right)\end{array}$ & $\begin{array}{l}\text { Pore volume } \\
(\mathrm{cc} / \mathrm{g})\end{array}$ & $\begin{array}{l}\text { Average pore } \\
\text { diameter }(\AA)\end{array}$ \\
\hline ZA1 & 203.58 & 0.37 & 71.71 \\
ZA2 & 177.87 & 0.27 & 60.30 \\
ZA3 & 27.43 & 0.04 & 46.46 \\
ZA4 & 45.23 & 0.06 & 49.60 \\
ZA5 & 39.74 & 0.15 & 147.73 \\
ZA6 & 33.54 & 0.08 & 94.15 \\
\hline
\end{tabular}

by their FESEM images (Fig. 3a, b). In case of the sample ZA3 the surface area suddenly reduced to $27 \mathrm{~m}^{2} / \mathrm{g}$ because of the heat treatment at $500{ }^{\circ} \mathrm{C}$ leading to the collapse of gel network structure. For the samples ZA4 and ZA6 the surface area decreased from 45 to $33 \mathrm{~m}^{2} / \mathrm{g}$ which may be due to an increase in the concentration of Brij-76 reduces the effective headgroup area and the repulsive forces between hydrophilic chains necessary for the gel network-formation [10]. The gel formation using surfactant can be considered as the electrostatic interactions between the ions of metal species and the head groups of charged surfactant [17]. The high-average pore diameter of $147 \AA$ of the sample ZA5 is in good agreement with the hysteresis loop of type $\mathrm{H}_{1}$ and increased pore volume [33].

FTIR spectra of the zirconia samples ZA2 and ZA4 are shown in Fig. 7. As seen in Fig. 7, a broad band is observed at around $3300 \mathrm{~cm}^{-1}$ which corresponds to the stretching vibration of the $\mathrm{O}-\mathrm{H}$ bond (due to physically adsorbed water). The bands at around 2970, 1340-1420 [34] and $845 \mathrm{~cm}^{-1}$ are due to $\mathrm{C}-\mathrm{H}$ (stretching, bending vibrations) and $\mathrm{Si}-\mathrm{C}$ bonds, respectively [7]. The bands in between 1000 and $1200 \mathrm{~cm}^{-1}$ correspond to the stretching vibration of $\mathrm{C}-\mathrm{O}$ bond which may be of Brij-76 [34]. The presence of the absorption bands at around 1260,950 and $650-750 \mathrm{~cm}^{-1}$ are assigned to the $\mathrm{Zr}-\mathrm{OPr}, \mathrm{Zr}-\mathrm{O}-\mathrm{Si}$ and $\mathrm{Zr}-\mathrm{O}$ bonds,

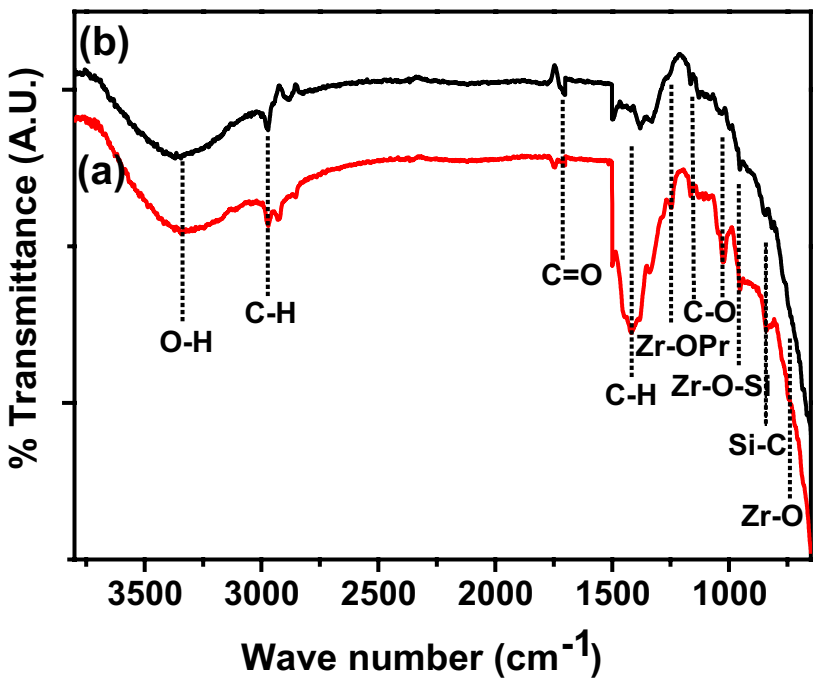

Fig. 7 FTIR spectra of the zirconia samples a ZA2, b ZA4

respectively [8]. The $\mathrm{C}-\mathrm{H}$ and $\mathrm{Si}-\mathrm{C}$ bonds band intensity decreased with increase in drying temperature from 150 to $500{ }^{\circ} \mathrm{C}$ indicating the decomposition of methyl groups. Further, there is a decrement in $\mathrm{C}-\mathrm{O}$ bond band intensity at $1024 \mathrm{~cm}^{-1}$ which may be due to the evaporation of Brij-76.

Amongst all the samples heat treated at $500{ }^{\circ} \mathrm{C}$, sample ZA4 has comparatively high surface area of $45 \mathrm{~m}^{2} / \mathrm{g}$ and small pores of around $50 \AA$, with collapse network structure as observed from FESEM image (Fig. 3d). But ZA2 have high surface area of $177 \mathrm{~m}^{2} / \mathrm{g}$ and average pore diameter of $60 \AA$ with highly ordered particles arrangement. These mesoporous zirconia aerogel powders can be used for catalysis purpose. Thus, the preparation of mesoporous zirconia aerogel powders employing surfactant and the studies on the influence of drying temperature and rate on their textural and mechanical properties will open new challenges in near future. 


\section{Conclusions}

Brij-76 mediated zirconia aerogel powders were successfully synthesized via ambient pressure drying method. The zirconia aerogel powders synthesized using Brij-76 (0.01 M) without any heat treatment exhibited the amorphous nature as confirmed by XRD analysis. FESEM image of the synthesized aerogel powders clearly demonstrated the regular periodic arrangement of zirconia particles. Further, they possessed the pore sizes of around $60 \AA$ and surface area nearly $177 \mathrm{~m}^{2} / \mathrm{g}$ as determined by $N_{2}$ adsorption-desorption analysis. FTIR spectra of the zirconia aerogels powder clearly showed the decrease of $\mathrm{C}-\mathrm{H}$ and $\mathrm{Si}-\mathrm{C}$ peak intensity with increase in the drying temperature from 150 to $500{ }^{\circ} \mathrm{C}$. These aerogel powders can be applied for the catalysis purpose.

Acknowledgements This study was financially supported by the Department of Science and Technology-Science \& Engineering Research Board (DST-SERB), New Delhi, India, through a major research project on 'aerogels' (no. SB/FTP/PS-030/2014). One of the authors, Uzma K. H. Bangi, is very grateful to the DST-SERB for Young Scientist Fellowship under fast-track scheme.

Open Access This article is distributed under the terms of the Creative Commons Attribution 4.0 International License (http://creativeco mmons.org/licenses/by/4.0/), which permits unrestricted use, distribution, and reproduction in any medium, provided you give appropriate credit to the original author(s) and the source, provide a link to the Creative Commons license, and indicate if changes were made.

\section{References}

1. Kistler, S.: Coherent expanded aerogels and jellies. Nature 127, 741 (1931)

2. Pajonk, G.: Transparent silica aerogels. J. Non-Cryst. Solids 225, 307-314 (1998)

3. Rao, A.V., Kulkarni, M.M.: Hydrophobic properties of TMOS/ TMES-based silica aerogels. Mater. Res. Bull. 37, 1667-1677 (2002)

4. Burchell, M., Graham, G., Kearsley, A.: Cosmic dust collection in aerogel. Annu. Rev. Earth Planet. Sci. 34, 385-418 (2006)

5. Wei, T., Lu, S., Chang, Y.: A new class of opacified monolithic aerogels of ultralow high-temperature thermal conductivities. J. Phys. Chem. C 113, 7424-7428 (2009)

6. Guo, X., Yan, L., Yang, H., et al.: Synthesis of zirconia aerogels by ambient pressure drying with propylene oxide addition. Acta Phys. Chim. Sinca 27(10), 2478-2484 (2011)

7. Bangi, U.K.H., Park, C.S., Baek, S., Park, H.H.: Sol-gel synthesis of high surface area nanostructured zirconia powder by surface chemical modification. Powder Techn. 239, 314-318 (2013)

8. Bangi, U.K.H., Jung, H., Park, C.S., et al.: Effect of thermal treatment on the textural properties and thermal stability of surface modified zirconia aerogel powders. Int. J. Nanotechnol. 13((4/5/6)), 52-462 (2016)
9. Crepaldi, E., Soler Illia, G., Grosso, D., et al.: Design and postfunctionalisation of ordered mesoporous zirconia thin Films, Chem. Commun. (Camb.), 1582-1583 (2001)

10. Jung, S., Ha, T., Seon, J., Park, H.: Phase behavior of ordered mesoporous silica film prepared by Brij-76 block copolymer. Micro. Meso. Mater. 111, 188-193 (2008)

11. Fujiwara, M., Yamamoto, F., Okamoto, K., et al.: Adsorption of duplex DNA on mesoporous silicas: possibility of inclusion of DNA into their mesopores. Anal. Chem. 78, 1367-1374 (2006)

12. Tozuka, Y., Sasaoka, S., Nagae, A.: Rapid adsorption and entrapment of benzoic acid molecules onto mesoporous silica (FSM-16). J. Colloid Int. Sci. 291, 471-476 (2005)

13. Cimino, S., Pirone, R., Lisi, L., et al.: Zirconia supported $\mathrm{LaMnO}_{3}$ monoliths for the catalytic combustion of methane. Appl. Catal. B: Env. 35, 243-254 (2002)

14. Bahamonde, A., Campuzano, S., Yates, M., et al.: Influence of zirconia raw materials on the development of $\mathrm{DeNO}_{\mathrm{x}}$ monolithic. Appl. Catal. B: Env. 44, 333-346 (2003)

15. Yamahara, K., Sholklapper, T., Jacobson, C., et al.: Ionic conductivity of stabilized zirconia networks in composite SOFC electrodes. Solid State Ionics 176, 1359-1364 (2005)

16. Huo, Q., Morgalese, D., Ciesla, U., et al.: Generalized synthesis of periodic surfactant/inorganic composite materials. Nature 368, 317-321 (1994)

17. Tanev, P., Pinnavaia, T.: A neutral templating route to mesoporous molecular sieves. Science 267, 865-867 (1995)

18. Soler-Illia, G., Scolan, E., Louis, A., et al.: Design of mesostructured titanium oxo based hybrid organic-inorganic networks. New J. Chem. 25, 156-165 (2001)

19. Hung, I., Hung, D., Fung, K., Hon, M.: Highly-ordered mesoporous nanocrystalline yttria-stabilized zirconia synthesized through evaporation-induced self-assembly method. Mater. Lett. 62, 1147-1150 (2008)

20. Hammouda, L., Mejri, I., Younes, M., Ghorbel, A.: Zirconia Aerogels. In: Agerter, M., Prassas, M. (eds.) Aerogels handbook, pp.127-143. Springer, Heidelberg (2012)

21. Ferino, I., Casula, M., Corrias, A., et al.: 4-Methylpentan-2-oldehydration over zirconia catalysts prepared by sol- gel. Phys. Chem. Chem. Phys. 2, 1847-1854 (2000)

22. Suh, Y., Moon, S., Rhee, H.: Active sited in $\mathrm{Cu} / \mathrm{ZnO} / \mathrm{ZrO}_{2}$ catalysts for methanol synthesis from $\mathrm{CO} / \mathrm{H}_{2}$. Catal. Today $\mathbf{6 3}$, 447-452 (2000)

23. Kalies, H., Pinto, N., Pajonk, G., et al.: Hydrogenation of formate species formed by $\mathrm{CO}$ chemisorption on a zirconia aerogel in the presence of platinum. Appl. Catal. A 202, 197-205 (2000)

24. Suh, Y., Moon, S., Rhee, H.: Synthesis of thermally stable tetragonal zirconia with large surface area and its catalytic activity in the skeletal isomerization of 1-butene. Catal. Lett. 90(1-2), 103-109 (2003)

25. Mejri, I., Younes, M., Ghorbel, A., et al.: Comparative study of the sulfur loss in the xerogel and aerogel sulfated zirconia calcined at different temperatures: effect on $n$-hexane isomerization. Stud. Surf. Sci. Catal. 162, 953-960 (2006)

26. Mejri, I., Younes, M., Ghorbel, A., et al.: Effect of the evacuation mode of solvent on the textural, structural nd catalytic properties of sulfated zirconia doped with cerium. Stud. Surf. Sci. Catal. 174, 493-496 (2008)

27. Chen, L., Hu, J., Ryan, M.: Catalytic properties of nanoscale iron-doped zirconia solid-solution aerogels. Chem. Phys. Chem. 9, 1069-1078 (2008)

28. Raissi, S., Younes, M., Ghorbel, A.: Synthesis and characterization of aerogel sulphated zirconia doped with chromium: $n$-hexane isomerization. J. Por. Mater. (2009). https://doi.org/10.1007/s1093 4-009-9289-0 
29. Dane, F., Sezginer, H., Yilmaz, G., et al.: An observation on the effects of Triton-X-405, Brij 35 and Brij 76 surfactant on the development of the seeds of Lens culinaris Medik. Biyoloji Bilimleri Araştırma Dergisi 8(2), 03-06 (2015)

30. Białon, J., Pajak, L., Jarzebski, A., et al.: Preparation effects on zirconia aerogel morphology. J. Non-Cryst. Solids 225, 115-119 (1998)

31. http://www.chemistrylearning.com/adsorptionisotherm/ (archived on March 6, 2009)

32. Ha, T., Im, H., Yoon, S., et al.: Pore structure control of ordered mesoporous silica film using mixed surfactants. J. Nanomater. 2011, 1-5 (2011)
33. Jung, S., Park, H.: Concentration-dependent mesostructure of surfactant-templated mesoporous silica thin film. Thin Solid Films 494, 320-324 (2006)

34. Silverstein, R., Bassler, G., Morrill, T.: Spectrometric Identification of Organic Compounds, 4th edn. John Wiley and Sons, New York (1981). (QD272.S6 S55)

Publisher's Note Springer Nature remains neutral with regard to jurisdictional claims in published maps and institutional affiliations. 